\title{
MIR10B wt Allele
}

National Cancer Institute

\section{Source}

National Cancer Institute. MIR10B wt Allele. NCI Thesaurus. Code C81878.

Human MIR10B wild-type allele is located in the vicinity of 2 q31.1 and is 109 bases in length. This allele, which encodes MIR10B pre-miRNA, plays a role in the regulation of gene expression. Alteration in the expression of this gene is associated with development of breast cancer. 